\title{
Stink Bug Population in Cotton Plantations with Different Plant Spacings
}

Izidro dos Santos de Lima Junior ${ }^{1}$

Paulo Eduardo Degrande ${ }^{2}$

Elmo Pontes de Melo ${ }^{3}$

Ligia Maria Maraschi da Silva Piletti ${ }^{4}$

Antonio Luiz Viegas Neto ${ }^{5}$

\section{Abstract}

The increase in cotton plant population by decreasing the spacing between rows cause some changes in phenotypical characteristics of cotton plants, such as decrease in number of leaves per plant, low-development leaves, and great soil shading. Stink bugs of the Pentatomidae family that migrate from soybean crops seem to benefit from the cotton narrow-row planting system. The objective of the present work was to evaluate adult and nymph stink bug populations in cotton plantations under three plant spacing. The experiment was conducted in the 2010/2011 cotton season at the Experimental Farm of the Federal University of Grande Dourados, in Dourados, MS, Brazil. A randomized block experimental design was used, with three cotton growing systems and eight replications, totaling 24 plots. The cotton growing systems were selected based on spacing between planting rows $(0.22,0.45$, and $0.90 \mathrm{~m})$. Five evaluations were conducted to survey the stink bug populations, with two samples per plot. The number of nymphs and adults of Euschistus heros and Edessa meditabunda was counted. The spacing between cotton planting rows affects stink bug populations of the species Euschistus heros and Edessa meditabunda. Increases in cotton plant density decrease the occurrence of stink bug in the plantation. The stink bug population is greater in cotton plantations with spacing of $0.90 \mathrm{~m}$ between planting rows.

Keywords: Narrow-row cotton. Pentatomidae. Environment.

\section{Introduction}

Plant spacing and density have been proposed for the growth of different plants; in the case of cotton, it has sought to meet specific needs regarding cultural practices, increasing yield, and decreasing production cost (BORIN et al., 2017). Several studies have addressed the decrease of space between planting rows and increase of number of plants per area. Silva et al. (2011a) found that the use of ultra-narrow-row spacing results in higher cotton yield than narrow-row and conventional

1 Instituto Federal de Educação, Ciência e Tecnologia de Mato Grosso do Sul (IFMS), professor EBTT. izidro.lima@ifms.edu.br. Rod. BR 463, s/n, Km 14, C. P.: 287, CEP: 79909-000.

2 Universidade Federal da Grande Dourados (UFGD), professor titular. paulo.degrande@outlook.com.

3 IFMS, professor EBTT. elmo.melo@ifms.edu.br.

4 IFMS, professor EBTT. ligia.piletti@ifms.edu.br.

5 IFMS, professor EBTT. antonio.viegas@ifms.edu.br. 
spacing, and the fiber technological characteristics are not affected by changes in spacing between planting rows.

The increase of plant populations by decreasing the spacing between rows may cause some changes in the phenotypical characteristics of cotton plants, such as decrease in number of leaves per plant, low-development leaves, and great soil shading (ROSOLEM et al., 2012). These factors can be correlated with decreases in number of reproductive structures by the plant but higher number per area; decreases in fertilization and weed control costs; and higher intercepting of solar radiation (CHIAVEGATO et al., 2010).

Changes in plant canopy caused by use of narrow-row planting system changes the microclimate on the soil surface, favoring the survival of some insects (PIERCE; MONK, 2007; MOLIN; HUGLE, 2010). Information about these changes are important to understand how microclimatic factors affect feeding behavior, dispersion, oviposition, and development of insect pests, and can contribute to the establishment of new pest management methods (PEDIGO; RICE, 2008).

The narrow-row system raises many questions regarding the favoring of populational dynamics of some Lepidoptera species, boll weevil, and Pentatomidae and Miridae stink bugs (AHMAD et al., 2009).

Pentatomidae stink bugs migrating from soybean crops seem to be favored by the narrow-row planting system due to the favorable characteristics to the reproductive stage of plants, which occurs at a short period in this system; and mainly throughout the time when cotton plants are present in the field, which can be targets for migration of large stink bug population from soybean crops at the end of cycle. Some studies on stink bugs migrant from soybean confirm that they infest cotton plantations and cause damages to them (SORIA et al., 2010), resulting in abscission of floral buds (WILLRICH et al., 2004) and small bolls (BOMMIREDDY et al., 2007), decreases in fiber quality when they attack medium to large bolls; and cotton seed yield up to $59.0 \%$ lower than plantations without stink bugs (MUSSER et al., 2008).

The first stink bugs are found in soybean crops soon after the emergence of plants; after some generations in the crop, which takes approximately 40 days each, the stink bug populations start to cause damages during the soybean reproductive period, when they are benefited by favorable climatic conditions and abundant feed, resulting in increases in their populations (SILVA et al., 2011b).

Stink bugs of the species Euschistus heros (FABRICIUS, 1974) (Hemiptera: Pentatomidae) and Edessa meditabunda (FABRICIUS, 1974) (Hemiptera: Pentatomidae) have been migrating to cotton plants in the last cotton seasons, after the soybean harvest, because cotton plants provide shelter and sources of feed that allow the maintenance and reproduction of these Pentatomidae species (AZAMBUJA, 2013). The mean longevity of $E$. meditabunda insects fed on cotton plants was 78.3 days for males and 83.5 days for females, with pre-oviposition period of 30.2 days and oviposition period of 23.2 days; and the percentage of ovipositing females was $90.0 \%$, with a mean of 55.2 eggs laid per female and 14 eggs per laying. The viability of eggs was $56.5 \%$, denoting that the species is capable of reproducing and generating offspring when fed on cotton plants (AZAMBUJA et al., 2015); E. heros presented similar results with longevity of approximately 37 days and nymph period of 41 days (AZAMBUJA, 2013).

The objective of this work was to evaluate adult and nymph stink bug populations in cotton plantations under three plant spacings and, thus, to explain the effects of the cotton narrow-row planting system on the incidence of these insect pests. 


\section{Material and methods}

The experiment was conducted in the 2010/2011 cotton season at the Experimental Farm of the Federal University of Grande Dourados (UFGD), in the municipality of Dourados, MS, Brazil (22 $2^{\circ} 4^{\prime} 05^{\prime \prime} \mathrm{S}, 5^{\circ} 59^{\prime} 19^{\prime \prime} \mathrm{W}$, and altitude of $\left.430 \mathrm{~m}\right)$.

The soil of the area was classified as Typic Hapludox (Latossolo Vermelho Distroférrico - SiBCS) of clayey texture; it was originally under a native vegetation of the Cerrado biome. The climate of the region is Am (tropical of monsoons), according to the Koppen classification. The total annual rainfall depth in the region is $1.400 \mathrm{~mm}$ to $1.500 \mathrm{~mm}$, and the average annual temperature is $22.0^{\circ} \mathrm{C}$ (Peel et al., 2007).

The experiment was implemented in an area of 2.0 ha with cotton plantations. The cotton plants were grown in three different planting systems: ultra-narrow row, narrow planting row, and conventional. The cotton seeds of the cultivar FMT 701 were sowed at the end of December 2010 with a sowing density of 9 seeds per meter; after germination, the population was 8 plants per meter in the three planting systems.

The plantation was conducted using the recommended agricultural practices for cotton in the central region of Brazil (EMBRAPA, 2011), without application of broad-spectrum insecticides to enable the establishment of the stink bugs populations in the plantations. Insecticide was used during the experiment only for control of cotton leafworm [Alabama argillacea (Hubner, 1818) (Lepidoptera: Noctuidae)] and tobacco budworm [Heliothis virescens (Fabricius, 1781) (Lepidoptera: Noctuidae)]; the insecticide used was lufenuron (Lufenurom $108 \mathrm{CE} ; 1.0 \mathrm{~L} \mathrm{ha}^{-1}$ ). The experiment was implemented at 71 days after the emergence of the plants (DAP), when they were at F2 phenological stage (MARUR; RUANO 2001).

The experiment was implemented in a randomized block design, with three cotton planting systems and eight replications, totaling 24 plots. The cotton planting systems were selected based on spacing between rows of $0.22,0.45$, and $0.90 \mathrm{~m}$ (TABLE 1 ).

Table 1 - Treatments, plant population, and space between rows of cotton plantation. Dourados, MS, Brazil, 2012.

\begin{tabular}{cccc}
\hline Treatment & Population $\left(\right.$ plant ha $\left.^{-1}\right)$ & Planting system & Space between rows $(\mathrm{m})$ \\
\hline 1 & 300.000 & Ultra-narrow-row & 0.22 \\
2 & 200.000 & Narrow-row & 0.45 \\
3 & 100.000 & Conventional & 0.90 \\
\hline
\end{tabular}

Source: Elaborated by the authors (2012).

The sample plot size was $12 \times 12 \mathrm{~m}$; each growing system had 8 plots (replications). The occurrence of stink bug populations was surveyed in 5 days throughout the cycle of the plants, with 12-day intervals between evaluations. The stink bug infestation in cotton plants occurred naturally. The infestation was evaluated using the beating cloth method, and all stink bugs present in it were counted. The beating cloth was 1.0-m length and 0.90-m width; the samples had the same proportion of sampled area in all spacings, with values adjusted by number of stink bugs per $0.90 \mathrm{~m}^{2}$. Two samplings were done per plot, using as evaluation the mean number of stink bugs (nymphs and 
adults) of the two samplings. After the counting, the insects were collected and taken to a laboratory for identification to the species level and, then, they were discarded.

The stink bugs found and used for evaluation were from the species Euschistus heros (Fabricius, 1974) (Hemiptera: Pentatomidae) and Edessa meditabunda (Fabricius, 1974) (Hemiptera: Pentatomidae). These species were chosen for evaluation because of their occurrence in cotton plantations (SÓRIA et al., 2010). The stink bugs were divided into nymphs and adults for counting.

Descriptive and exploratory statistical analysis was carried out, using graphs for analysis of population dynamics. The data were subjected to analysis of variance by the $\mathrm{F}$ test and, when significant, the means were compared by the Tukey's test at $5 \%$ significance.

\section{Results and discussion}

A total of 1,705 stink bugs were collected: $92 \%$ of them were from the species Euschistus heros, and the remainder were from the species Edessa meditabunda.

The number of adult stink bugs was higher than that of nymphs in all evaluations. The number of adult stink bugs increased as the spacing between planting rows was increased (FIGURE 1) (TABLE 2). This result may be due to the evaluation time, which was by the end of the soybean crop cycle in the region, making the stink bugs to migrate to cotton plantations and establish their population when they were at the initial reproduction process.

The plants grown in the narrow-row planting system presented better interception of solar radiation, which resulted in higher leaf area and faster closure of plant canopy between rows, favoring soil shading and decreasing the air temperature under the plantation canopy (SILVA et al., 2006). This may have favored the stink bug population, which presented higher number of nymphs in the planting spacing of $0.22 \mathrm{~m}$.

The presence of nymphs in the evaluations indicates that the stink bugs were reproducing in the cotton plantation and were probably attracted to the spacing of $0.22 \mathrm{~m}$ for reproduction because of the characteristics of this plantation. The quantity of adult stink bugs depended on the planting row spacing: the population increased as the spacing between rows was increased. 
Figure 1. Adult and nymph populations of stink bugs of the species Euschistus heros and Edessa meditabunda as a function of spacing between planting rows, found in five evaluations during the cotton plant cycle. Dourados, MS, Brazil, 2012.

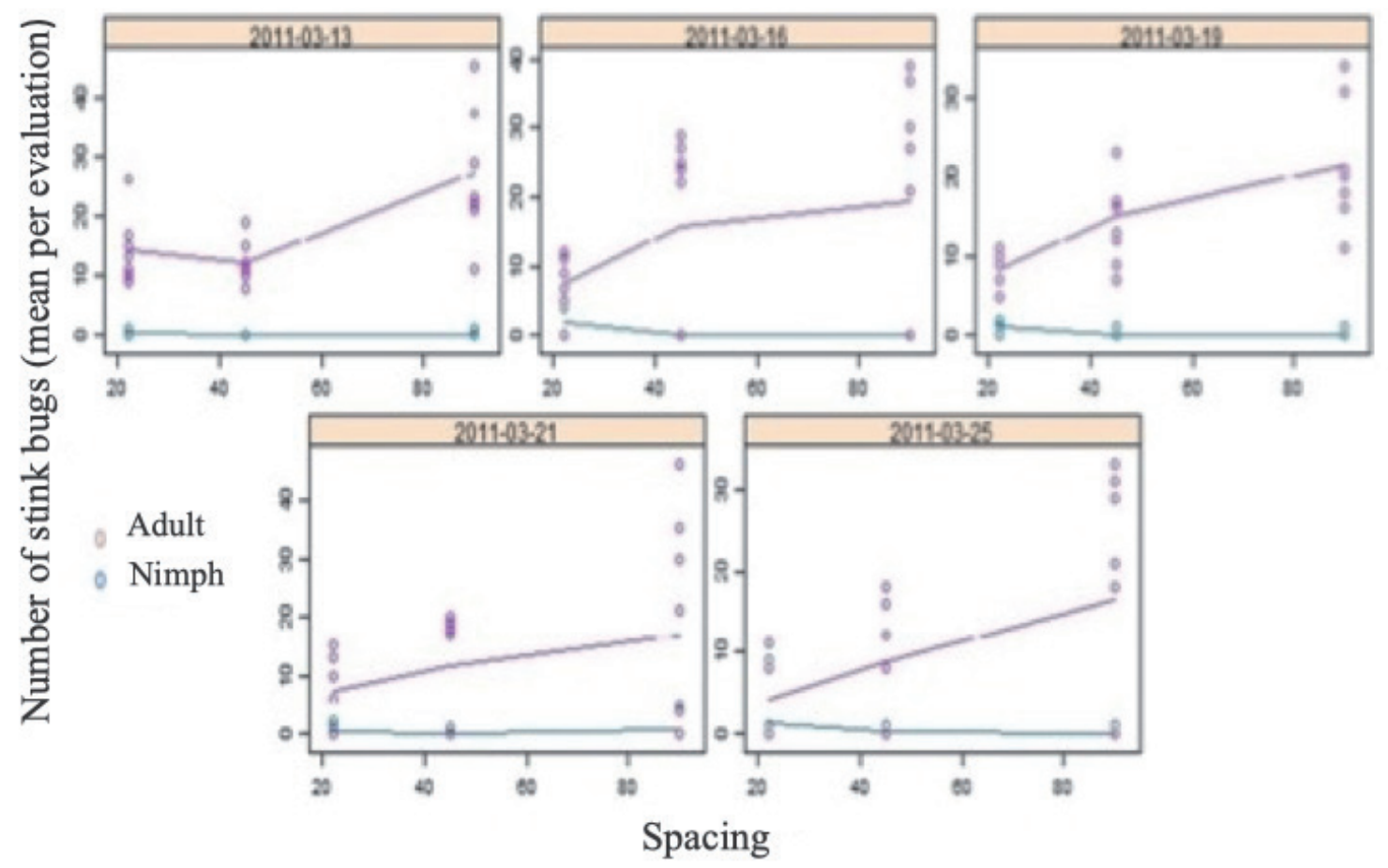

Source: Elaborated by the authors (2012).

According to Corrêa-Ferreira and Panizzi (1999), the level for control of stink bugs in soybean crops is 4 adult stink bugs per beating cloth for plants at reproductive period; thus, the evaluations showed higher numbers than that indicated for soybean crops. This can be explained by the experiment time, when most soybean crops had already been harvested, making the cotton plants of the experimental area become attractive for most stink bugs (SORIA et al., 2010).

The adult stink bug population was statistically higher in the spacing of $0.90 \mathrm{~m}$ between planting rows than in the other treatments, considering the total of all evaluations. The number of adult stink bugs decreased as the spacing between planting rows decreased and the plant population increased. The number of nymph stink bugs found in the treatment 0.22-m planting row spacing was significantly different from the other treatments, presenting higher means, which indicates a preference of Pentatomidae species for oviposition in this plant spacing (TABLE 2).

The lower number of nymphs than adults in the cotton plants in all evaluations may be related to the time that stink bugs need to reach sexual maturity, and incubation of eggs (approximately 24 days). Moreover, the stink bugs were in process of migration to another plant, and they were still adapting to the new environment. The lower number of nymphs in the plots can be explained by the beginning of the diapause period of the stink bugs, when they need to store high amount of lipids to survive in the period without feed, which makes them to spend less energy for mating. Some insect-pest species, such as Bemisia tabaci (GENNADIUS) (Hemiptera: Aleyrodidae), Pectinophora gossypiella 
(SAUNDERS, 1844) (Lepidoptera: Gelechiidae), and Heliothis spp. (Lepidoptera: Noctuidae), are not affected by plant spacing and population (AHMAD et al., 2009).

Table 2. Mean number of adult and nymph stink bugs of the species Euschistus heros and Edessa meditabunda (Pentatomidae) as a function of spacing between planting rows, considering the total of all evaluations during the cotton plant cycle. Dourados, MS, Brazil, 2012.

\begin{tabular}{ccc}
\hline \multirow{2}{*}{ Spacing } & \multicolumn{2}{c}{ Evaluation } \\
\cline { 2 - 3 } & Adult & Nymph \\
\hline $0.22 \mathrm{~m}$ & $8.3 \mathrm{a}^{*}$ & $1.0 \mathrm{~b}$ \\
$0.45 \mathrm{~m}$ & $12.7 \mathrm{a}$ & $0.1 \mathrm{a}$ \\
$0.90 \mathrm{~m}$ & $20.3 \mathrm{~b}$ & $0.2 \mathrm{a}$ \\
\hline $\mathrm{F}$ & 29.32 & 5.64 \\
\hline
\end{tabular}

Means followed by the same letter in the columns are not different by the Tukey's test at $5 \%$ probability.

Source: Elaborated by the authors (2012).

The comparison of the number of adult stink bugs found in each evaluation showed that in only one evaluation in the spacing of $0.90 \mathrm{~m}$ the mean number of number of adult stink bugs was statistically similar to that in the other spacing evaluated, although it was higher than that of the other treatments. All treatments were significantly different in the last evaluation (TABLE 3). The high number of stink bugs found in the plots may be related to the time the experiment was implemented, since the occurrence of brown stink bug population occurs from November to April, but the population peak of this insect occurs from March to April (CORREAA-FERREIRA; PANIZZI, 1999)

$E$. heros insects complete approximately three generations throughout the soybean crop cycle, and after harvesting, they disperse, finishing their life cycle feeding on alternative hosts. This occurs for the whole soybean stink bug complex; after dispersion, they can infest plantations that still are at the vegetative stage, such as maize and wheat crops, or at the reproductive stage, such as cotton (PANIZZI, 2000), influenced by the plant spacing and population. Stink bugs migrate to other hosts searching for better conditions of shelter, feeding, and reproduction.

Table 3. Mean number of adult stink bugs of the species Euschistus heros and Edessa meditabunda (Pentatomidae) as a function of spacing between planting rows, in five evaluations during the cotton plant cycle. Dourados, MS, Brazil, 2012.

\begin{tabular}{cccccc}
\hline \multirow{2}{*}{ Spacing } & \multicolumn{5}{c}{ Evaluation } \\
\cline { 2 - 6 } & $\mathbf{0 3 / 1 3 / 1 1}$ & $\mathbf{0 3 / 1 6 / 1 1}$ & $\mathbf{0 3 / 1 9 / 1 1}$ & $\mathbf{0 3 / 2 1 / 1 1}$ & $\mathbf{0 3 / 2 5 / 1 1}$ \\
\hline $0.22 \mathrm{~m}$ & $14.1 \mathrm{a}^{*}$ & $7.5 \mathrm{a}$ & $8.3 \mathrm{a}$ & $7.4 \mathrm{a}$ & $4.4 \mathrm{a}$ \\
$0.45 \mathrm{~m}$ & $12.2 \mathrm{a}$ & $15.9 \mathrm{a}$ & $15.1 \mathrm{ab}$ & $17.8 \mathrm{ab}$ & $12.8 \mathrm{~b}$ \\
$0.90 \mathrm{~m}$ & $27.1 \mathrm{~b}$ & $19.2 \mathrm{a}$ & $21.5 \mathrm{~b}$ & $24.3 \mathrm{~b}$ & $26.5 \mathrm{c}$ \\
\hline $\mathrm{F}$ & 14.7 & 3.09 & 20.8 & 11.9 & 79.2 \\
\hline
\end{tabular}

Means followed by the same letter in the columns are not different by the Tukey's test at $5 \%$ probability.

Source: Elaborated by the authors (2012). 
The treatment with spacing of $0.22 \mathrm{~m}$ between planting rows presented higher number of nymph stink bugs in most evaluations, significantly differing from the treatment with spacing of $0.90 \mathrm{~m}$ by presenting higher number in two evaluations. The treatment with spacing of $0.90 \mathrm{~m}$ had higher number of nymph stink bugs in only one evaluation, at 03/21/2011 (TABLE 4). The number of nymphs was practically stable throughout the evaluations, indicating that although the adult population was high, the stink bugs were not yet reproducing. Although studies confirm the damages caused by stink bugs in cotton plants (SORIA et al., 2009; SORIA et al., 2010), their reproduction rate is not yet known.

Some discussions can be made about the low nymph population found: their infestation period, in which the population is establishing in the plantation; their non-preference feeding for cotton plants; the stink bug needs to store high lipid amounts, which prevents them to mate, making them to only finishing their life cycle with low quantity of feed, for the diapause; and females decrease their oviposition rates as their longevity increases.

Table 4. Mean number of nymph stink bugs of the species Euschistus heros and Edessa meditabunda (Pentatomidae) as a function of spacing between planting rows, in five evaluations during the cotton plant cycle. Dourados, MS, Brazil, 2012.

\begin{tabular}{cccccc}
\hline \multirow{2}{*}{ Spacing } & \multicolumn{5}{c}{ Evaluation } \\
\cline { 2 - 6 } & $\mathbf{0 3 / 1 3 / 1 1}$ & $\mathbf{0 3 / 1 6 / 1 1}$ & $\mathbf{0 3 / 1 9 / 1 1}$ & $\mathbf{0 3 / 2 1 / 1 1}$ & $\mathbf{0 3 / 2 5 / 1 1}$ \\
\hline $0.22 \mathrm{~m}$ & $0.4 \mathrm{a}$ & $2.0 \mathrm{a}$ & $1.0 \mathrm{a}$ & $0.5 \mathrm{a}$ & $1.3 \mathrm{~b}$ \\
$0.45 \mathrm{~m}$ & $0.0 \mathrm{a}$ & $0.0 \mathrm{a}$ & $0.1 \mathrm{~b}$ & $0.1 \mathrm{a}$ & $0.6 \mathrm{ab}$ \\
$0.90 \mathrm{~m}$ & $0.1 \mathrm{a}$ & $0.0 \mathrm{a}$ & $0.1 \mathrm{~b}$ & $0.9 \mathrm{a}$ & $0.1 \mathrm{a}$ \\
\hline $\mathrm{F}$ & 1.02 & 4.03 & 2.03 & 0.72 & 1.44 \\
\hline
\end{tabular}

Means followed by the same letter in the columns are not different by the Tukey's test at $5 \%$ probability.

Source: Elaborated by the authors (2012).

\section{Conclusion}

The spacing between cotton planting rows affects stink bug populations of the species Euschistus heros and Edessa meditabunda;

Increases in cotton plant density decrease the occurrence of stink bug in the plantation;

The stink bug population is greater in cotton plantations with spacing of $0.90 \mathrm{~m}$ between planting rows;

\section{População de percevejos em diferentes espaçamentos de cultivo de algodoeiro}

\section{Resumo}

Algumas modificações nas características fenotípicas das plantas de algodão, como diminuição no número de folhas por planta, folhas com desenvolvimento reduzido e maior sombreamento do solo são causadas pelo aumento da população de plantas e diminuição no espaçamento entrelinhas. Os 
percevejos migrantes da soja da família Pentatomidae aparentam ser beneficiados por este sistema adensado. 0 presente trabalho teve por objetivo avaliar a população de percevejos adultos e ninfas em três espaçamentos de cultivo do algodão. 0 trabalho foi realizado na Fazenda Experimental da Universidade Federal da Grande Dourados no município de Dourados na safra 2010/2011. 0 delineamento experimental foi de blocos ao acaso em três sistemas de cultivo do algodoeiro com oito repetições totalizando 24 parcelas. Os sistemas de cultivos foram divididos em relação aos espaçamentos entrelinhas: 0,22, 0,45 e 0,90 m. Foram realizadas cinco avaliações para levantamento da população de percevejos, sendo duas amostragens por parcela. Procedeu-se à contagem do número de ninfas e adultos de Euschistus heros e Edessa meditabunda. Há efeito do espaçamento sobre a população dos percevejos Euschistus heros e Edessa meditabunda. O adensamento do algodoeiro reduziu a presença de percevejo na lavoura. A população de percevejos é maior no espaçamento entrelinha de 0,90 m.

Palavras-chave: Cultivo adensado. Pentatomidae. Ambiente.

\section{Referências}

AHMAD, A. U. H.; ALI, R.; ZAMIR, S. I.; MAHMOOD, N. Growth, yield and quality performance of cotton cultivar BH-160 (Gossypium hirsutum L.) as influenced by different plant spacing. The Journal of Animal \& Plant Sciences, v. 19, n. 4, p. 189-192.

AZAMBUJA, R.; DEGRANDE, P. E. ; SOUZA, E. P. ; PEREIRA, F. F; PASTORI, P. L. Reprodução de Edessa meditabunda (Hemiptera: Pentatomidae) em algodoeiro. Acta Biologica Colombiana, v. 20, p. 203-208, 2015.

AZAMBUJA, R; DEGRANDE, P. E; PEREIRA, F. F. Comparative Biology of Euschistus heros (F.) (Hemiptera: Pentatomidae) feeding on Cotton and Soybean Reproductive Structures. Neotropical Entomology, v. 42, p. 359/365, 2013.

BOMMIREDDY, P. L.; LEONARD, B. R.; TEMPLE, J. H. Influence of Nezara viridula feeding on cotton yield, fiber quality, and seed germination. Journal of Economic Entomology, Lanham, v. 100, p. 1560-1568, 2007.

BORIN, A. L. D. C.; FERREIRA, A. C. B.; SOFIATTI, V.; CARVAlHO, M. C. S.; MORAES, M. C. G. Produtividade do algodoeiro adensado em segunda safra em resposta à adubação nitrogenada e potássica. Revista Ceres, Viçosa, v. 64, n. 6, p. 622-630, 2017.

CHIAVEGATO, E. J.; SILVA, A. V.; GOTTARDO, L. C. B. Densidade e arranjo de plantas em sistema adensado. In: BELOT, J. L.; VILELA. P. A. (Org.). O Sistema de cultivo do algodoeiro adensado em Mato Grosso. Cuiabá: Defanti, 2010. v. 1, p. 121-134.

CORRÊA-FERREIRA, B. S.; PANIZZI, A. R. Percevejos da soja e seu manejo. Londrina: EMBRAPA-CNPSo, 1999. 45p. (EMBRAPA-CNPSo. Circular Técnica, 24). 
EMBRAPA AGROPECUÁRIA OESTE. Produção sustentável de algodão. Dourados, 2011. 27p.

MARUR, C. J.; RUANO, O. A reference system for determination of developmental stages of upland cotton. Revista de Oleaginosas e Fibrosas, Campina Grande, v. 5, n. 1, p. 313-317, 2001.

MOLIN, W. T.; HUGIE, J. A. Effects of population density and nitrogen rate in ultra narrow row cotton. SRX Agriculture, v. 2010, n. 1, p. 1-6, 2010. DOI: 10.3814/2010/868723.

MUSSER, F. R; KNIGHTEN, K. S.; REED, J. T. Comparison of cotton damage from tarnished plant bug (Hemiptera: Miridae) and southern green stink bug (Hemiptera: Pentatomidae) adults and nymphs. Midsouth Entomologist, Starkville, v. 2, n. 1, p. 1-9, 2008.

PANIZZI, A. R. Suboptimal nutrition and feeding behavior of hemipterans on less preferred plant food sources. Anais da Sociedade Entomológica do Brasil, Londrina, v. 29, n. 1, p. 1-12, mar. 2000.

PEDIGO, L. P.; RICE, M. E. Entomology and pest management. 6. ed. Columbus: Prentice Hall, 2008. 816p.

PEEL, M. C.; FINLAYSON, B. L.; McMAHON, T. A. Updated world mapofthe KöppenGeiger climate classification. Hydrologyand Earth System Sciences, v. 11, p. 1633-1644, 2007.

PIERCE, J. B.; MONK, P. Y. Influence of management on crop microclimate and control of cotton Bollworm, Helicoverpa zea Boddle. In: The world cotton research conference-4, 2007. Lubbock, TX. Proceedings... Disponível em: <http://wcrc.confex.com/wcrc/2007/techprogram/P2072.HTM>. Acesso em: 16 dez. 2012.

ROSOLEM, C. A.; ECHER, F. R.; LISBOA, I. P.; BARBOSA, T. S. Acúmulo de nitrogênio, fósforo e potássio pelo algodoeiro sob irrigação cultivado em sistemas convencional e adensado. Revista Brasileira de Ciência do Solo, v. 36, n. 1, p. 457-466, 2012.

SILVA, A. V.; CHIAVEGATO, E. J.; CARVALHO, L. H.; KUBIAK, D. M. Crescimento e desenvolvimento do algodoeiro em diferentes configurações de semeadura. Bragantia, Campinas, v. 65, n. 3, p. 407$411,2006$.

SILVA, A. V.; CHIAVEGATO, E. J. ; CARVALHO, L. H. ; FURLANI JUNIOR, E.; KONDO, J. I.; SALVATIERRA, D. K. ; TISSELLI, A. C. P. C. Configurações de semeadura e produção e qualidade da fibra do algodoeiro Sowing configurations and yield and cotton fiber quality. Semina: Ciências Agrárias, v. 32, p. 1709 - 1716, 2011.

SILVA, F. A. C.; CALIZOTTI, G. S.; PANIZZI, A. R. Survivorship and egg production of phytophagous pentatomids in laboratory rearing. Neotropical Entomology, v. 40, p. 35-38, 2011.

SORIA, M. F.; DEGRANDE, P. E.; PANIZZI, A. R. Algodoeiro invadido. Revista Cultivar: Grandes Culturas, Pelotas, v. 131, n. 1, p. 18-20, 2010.

SORIA, M. F.; THOMAZONI, D.; MARTINS, R. R.; DEGRANDE, P. E. Stink bug incidence on Bt cotton in Brazil. In: Beltwide Cotton Conferences, San Antonio. Proceedings..., p. 813-819, 2009. 
WILLRICH, M. M.; LEONARD, B. R.; GABLE, R. H.; LAMOTTE, L. R. Boll injury and yield losses in cotton associated with brown stink bug (Heteroptera: Pentatomidae) during flowering. Journal of Economic Entomology, Lanham, v. 97, n. 1, p. 1928-1934, 2004.

Received: September 4, 2018

Accepted: March 20, 2019 